Jurnal Basicedu Volume 4 Nomor 1 Januari 2020 Halaman 22-28

JURNAL BASICEDU

Research \& Learning in Elementary Education

https://jbasic.org/index.php/basicedu

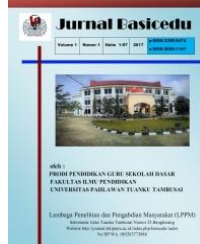

\title{
PENGEMBANGAN KETERAMPILAN MENULIS DENGAN MENGGUNAKAN MEDIA UNTUK MENINGKATKAN HASIL BELAJAR DI SEKOLAH DASAR
}

\author{
Adnan ${ }^{1}$, Riski Kurniawati ${ }^{2}$ \\ Universitas Syiah Kuala,Banda Aceh, Indonesia, ${ }^{1}$ \\ Unversitas Iskandarmuda, Indonesia ${ }^{2}$ \\ E-mail: sadnanabdullah408@gamil.com ${ }^{1}$,
}

\begin{abstract}
Abstrak
Tujuan penelitian ini adalah untuk mengetahui peningkatan hasil belajar dan ketrampilan menulis dengan menggunakan media yang bertuliskan kata dan kalimat. Metode yang digunakan adalah Penelitian Tindakan Kelas (PTK) dan yang menjadi subjek adalah siswa sekolah dasar semester genap tahun pelajaran 2015/2016. Tindakan yang dilaksanakan ada dua siklus. Pada siklus I rata-rata hasil belajar siswa diperoleh dengan nilai 61,9 yang terdiri 11 siswa tuntas $(47,82 \%)$ dan 12 siswa $(52,18 \%)$ tidak tuntas. Untuk siklus II nilai hasil belajar meningkat dengan nilai rata-rata 78,26. siswa yang mencapai ketuntasan pada siklus II berjumlah 21 siswa $(91,30)$ dan yang tidak tuntas berjumlah 2 siswa $(8,70 \%)$. rata-rata nilai siklus II diatas KKM yang telah ditetapkan oleh sekolah yaitu 65 . ketuntasan secara klasikal $80 \%$ meningkat dari $47,82 \%$ pada siklus I menjadi 91,30\%. Dengan demikian melalui pembelajaran menggunakan media dapat meningkatkan keterampilan menulis siswa di Sekolah Dasar.
\end{abstract}

Kata Kunci : Keterampilan menulis, media

\begin{abstract}
The purpose of this paper is to know the improvement of learning outcomes and writing skills using media that read words and sentences. The method used is Classroom Action Research (PTK) and the subject is elementary school students even semester 2015/2016 school year. The action carried out there are two cycles. In the first cycle of student learning outcomes obtained with a value of 61.9 consisting of 11 students complete $(47.82 \%)$ and 12 students $(52.18 \%)$ is not complete. For the second cycle the value of learning achievement increased with the average value of 78.26. students who achieved completeness in cycle II amounted to 21 students (91.30) and who did not complete amounted to 2 students $(8.70 \%)$. the average value of cycle II above the KKM that has been established by the school that is $65.80 \%$ classical completeness increased from $47.82 \%$ in the first cycle to $91.30 \%$. Thus through learning using the media can improve the writing skills of students in Primary School.
\end{abstract}

Keyword : Writing skill, media

@ Jurnal Basicedu Prodi PGSD FIP UPTT 2020

$\bowtie$ Corresponding author :

Address :-

Email :-

ISSN 2580-3735 (Media Cetak)

Phone :-

\author{
ISSN 2580-1147 (Media Online)
}


23 Pengembangan keterampilan menulis dengan menggunakan media untuk meningkatkan hasil belajar di sekolah dasar - Adnan, Riski Kurniawati

\section{PENDAHULUAN}

Kemampuan menulis merupakan suatu ketrampilan yang perlu dibekali kepada murid sekolah dasar pada kelas awal. Kemampuan awal siswa dapat menulis lanjut sehingga mampu mengeluarkan ide dan gagasan yang ingin disampaikan kepada orang lain. Menulis merupakan kegiatan yang sifatnya berkelanjutan sehingga pembelajarannyapun perlu dilakukan secara berkesinambungan sejak sekolah dasar. Keterampilan menulis kata dan kalimat merupakan kemampuan dasar sebagai bekal menulis tingkat lanjutan, oleh karena itu menulis kata dan kalimat harus mendapat perhatian secara optimal khusus pada kelas I sekolah dasar sehingga dapat memenuhi target kemampuan menulis seperti yang diharapkan

Pembelajaran bahasa Indonesia bertujuan agar siswa mampu menguasai bahasa secara lisan dan tulisan, namun kenyataannya dilapangan diluar yang diharapkan. Berdasarkan dari hasil observasi pada tanggal 25 februari 2016 ditemukan pada sekolah dasar masih ada siswa belum memiliki kemampuan menulis kata dan kalimat yang ditulis guru dipapan tulis secara rapi dan benar, ada sebagian siswa belum dapat menggabungkan menulis huruf dan ada juga belum dapat menulis kata secara tepat dan benar serta tidak bersemangat dalam menulis. sehingga banyak siswa yang belum tuntas. Nilai ketuntasan minimum (KKM) disekolah dasar tersebut adalah 65. Rendahnya aktivitas dan hasil belajar siswa tersebut perlu ditingkatkan. Salah satu caranya adalah dengan merubah proses pembelajaran guru. Jika selama ini proses pembelajaran masih berpusat pada guru, sehinggan perlu diterapkan pembelajaran yang lebih menyenangkan, berbeda dari sebelumnya [9]. Proses pembelajaran yang diterapkan harus mampu meningkatkan kreatifitas siswa dalam memecahkan masalah terutama masalah peningkatan kemampuan menulis kata dan kalimat secara tepat dan benar pada siswa sekolah dasar. Salah satu usaha yang harus dilakukan adalah guru melakukan proses pembelajaran dengan menggunakan media bertulisan kata dan kalimat. Dengan demikian diharapkan melalui penggunaan media hasil belajar siswa semakin meningkat.

Berdasarkan identifikasi masalah yang telah diuraikan di atas, dapat dirumuskan masalahnya yaitu Apakah dengan menggunakan media bertuliskan kata dan kalimat siswa mampu mengembangkan ketrampilan menulis, sehingga meningkatnya hasil belajar siswa di sekolah dasar. Ttujuan pada makalah ini adalah untuk mengembangkan keterampilan menulis dengan menggunakan media bermain botol meningkatkan hasil belajar siswa sekolah dasar.

Langkah-langkah kegiatan menulis pemula terbagi dua, yaitu pengenalan huruf dan latihan. Salah satu contoh pembelajaran pengenalan bentuk tulisan untuk murid sekolah dasar misalnya guru hendak memperkenalkan siswa mengajak latihan fokus dalam menulis. Proses pemberian latihan dilaksanakan dengan mengikuti prinsip-prinsip dari mudah ke yang sukar, dari latihan sederhana kelatihan yang lebih komplek. Ada beberapa bentuk latihan menulis permulaan yang dapat kita lakukan antara lain:

1. Latihan memegang pensil dan duduk sikap posisi yang benar.

2. Latihan gerak tangan latihan mengeblok yakni menirukan atau menebalkan suatu tulisan dengan menindas tulis yang telah ada.

3. Latihan menghubung-hubungkan tanda titik yang membuat tulisan.

4. Latihan menatap bentu tullisan.

5. Latihan menyalin baik dari buku maupun dari tulisan guru pada papan tulis

6. Latihan menulis halus indah

7. Latihan dikte/imla' 
24 Pengembangan keterampilan menulis dengan menggunakan media untuk meningkatkan hasil belajar di sekolah dasar - Adnan, Riski Kurniawati

8. Latihan melengkapi tulisan (latihan melengkapi huruf, suku kata atau kata) yang secara sengaja dihilangkan[7].

Pembelajaran menulis bagi anak sekolah dasar yang baru belajar merupakan hal paling sulit bagi anak. Mereka perlu menguasai sejumlah keterampilan yaitu kemampuan mengenal huruf, mengeja huruf-huruf yang akan ditulis yang dapat membentuk sebuah kata yang bermakna yang menggambarkan huruf yang dimaksud. Metode yang dapat digunakan menulis diantaranya :

1. Menulis dengan berbagai cara dan berbagai media yaitu sebelum menulis siswa diberikan berbagai media untuk melatih motorik halusnya dengan cara menebalkan garisputus-putus.

2. Menulis huruf yaitu diperkenalkan huruf yang memudahkan siswa menulis huruf lainnya.

3. Menulis kata yaitu guru memvariasikan huruf dengan kata misalnya siswa sedang menulis huruf a, mintalah siswa mencari benda yang dimulai dengan huruf a seperti apel dan ayam

4. Menulis kalimat yaitu kegiatan ini merupakan variasi lain dari kegiatan menulis huruf atau hand writing. Siswa diminta untuk mencari kata-kata yang dimulai dengan huruf depan yang sama misalnya saya suka susu atau minta mie [8].

Kata media berasal dari kata latin, merupakan bentuk jamak dari kata "medium"yang secara harfiah kata tersebut mempunyai arti perantara atau pengantar. Beberapa definisi menurut para ahli tentang multimedia. Media adalah alat bantu apa saja yang dapat dijadikan sebagai penyalur pesan guna mencapai tujuan pembelajaran[4]. Media adalah segala sesuatu yang dapat digunakan untuk menyalurkan pesan dari pengirim ke penerima sehingga dapat merangsang pikiran, perasaan, perhatian dan minat siswa sedemikian rupa sehingga terjadi proses belajar[9]. Jadi, media merupakan alat perantara yang diciptakan untuk menyalurkan pesan dengan tujuan agar pemakai dapat lebih mudah dalam mencapai suatu tujuan.

Keterampilan menulis bagi anak sekolah dasar yang baru belajar merupakan hal paling sulit bagi anak. Mereka perlu menguasai sejumlah keterampilan yaitu kemampuan mengenal huruf, mengeja huruf-huruf yang akan ditulis yang dapat membentuk sebuah kata yang bermakna yang menggambarkan huruf yang dimaksud maka diperlukan suatu media yang tepat supaya dapat tercapai tujuan menulis yang baik dan benar.

Untuk tercapainya ketrampilan menulis pada siswa pemula dapat digunakan bermacammacam media sehingga dengan memanfaatkan media tersebut siswa akan lebih mudah memahami dan mempraktekkan serta lebih bergairah dalam belajar. Pemakaian media pembelajaran dalam proses belajar mengajar dapat membangkitkan keinginan dan minat yang baru, membangkitkan motivasi dan rangsangan kegiatan belajar, dan bahkan membawa pengaruh-pengaruh psikologis terhadap siswa. Penggunaan media harus disesuaikan dengan psikologis siswa agar tujuan pembelajaran dapat tercapai dengan yang diharapkan oleh guru materi yang disampaikan dapat dilakukan dengan tepat oleh siswa. Manfaat praktis dari penggunaan media pembelajaran di dalam pembelajaran adalah sebagai berikut.:

1. Media pembelajaran dapat memperjelas penyajian pesan dan informasi sehingga dapat memperlancar dan meningkatkan proses dan hasil belajar.

2. Media pembelajaran dapat meningkatkan dan mengarahkan perhatian anak sehingga dapat meningkatkan motivasi belajar, interaksi yang lebih langsung antara siswa dan lingkungan, dan kemungkinan untuk belajar sendiri-sendiri sesuai dengan kemampuan dan minatnya.

3. Media pembelajaran mengatasi keterbatasan indera, ruang dan waktu. 
25 Pengembangan keterampilan menulis dengan menggunakan media untuk meningkatkan hasil belajar di sekolah dasar - Adnan, Riski Kurniawati

4. Media pembelajaran dapat memberikan kesamaan pengalaman kepada siswa tentang peristiwa dilingkungan mereka, serta memungkinkan terjadinya interaksi langsung dengan guru, masyarakat dan lingkungan

Media yang digunakan dalam menulis kata dan kalimat yaitu media bermain botol bertuliskan kata dan kalimat. diharapkan akan tercapai tujuan menulis karena media ini untuk membantu siswa dalam menulis yang baik dan benar serta dapat menyenangkan siswa dalam menulis kata dan kalimat.

\section{METODE}

Penelitian yang dilakukan adalah Penelitian Tindakan Kelas (PTK). Kemmis dan Mc. Taggart (1988) : PTK adalah studi yang dilakukan untuk memperbaiki diri sendiri, pengalaman kerja sendiri yang dilaksanakan secara sistematis, terencana, dan dengan sikap mawas. Jadi Penelitian tindakan kelas merupakan terjemahan dari Classroom Research, yaitu satu action research yang dilakukan oleh guru di dalam kelasnya sendiri melalui refleksi diri, dengan tujuan untuk memperbaiki kinerjanya sebagai guru, sehingga hasil belajar siswa menjadi menjadi meningkat.

\section{HASIL DAN PEMBAHASAN}

$\begin{array}{ccr}\text { Berdasarkan hasil belajar siswa } & \text { setelah } \\ \text { diterapkan penggunaan media untuk }\end{array}$
mengembangkan ketrampilan menulis pada siswa sekolah dasar, menunjukan mencapai nilai ketuntasan belajar adalah 61,96. Hasil tersebut menunjukan nilai ketuntasan masih dibawah nilai KKM yakni nilai 65 . Hasil belajar pada siklus I belum mencapai ketuntasan. Persentase nilai dapat dilihat pada tabel 3 dibawah ini:
Tabel 1. Klasifikasi Nilai Hasil Belajar siswa siklus I

\begin{tabular}{|l|l|l|l|}
\hline Nilai & Klasifikasi & Frekwensi & Persentase \\
\hline $86-100$ & Sangat baik & & \\
\hline $76-85$ & baik & 1 & $4,4 \%$ \\
\hline $66-75$ & Cukup & 3 & $13,0 \%$ \\
\hline $50-65$ & Kurang & 18 & $78,2 \%$ \\
\hline $0-49$ & $\begin{array}{l}\text { Sangat } \\
\text { Kurang }\end{array}$ & 1 & $4,4 \%$ \\
\hline & Jumlah & 23 & $100 \%$ \\
\hline
\end{tabular}

Dari tabel 1 dapat diketahui siswa yang memperoleh nilai sangat baik (86-100) tidak ada, siswa yang memperoleh nilai baik(76-85) 1 orang siswa $(4,4 \%)$, siswa yang memperoleh nilai cukup ( 66-75) sebanyak $3(13,0 \%)$ siswa, siswa yang memperoleh nilai kurang (50-65) sebanyak 18 ( $78,2 \%$ ) siswa serta siswa yang memeroleh nilai sangat kurang ( 0-49) sebanyak 1( 4,4) siswa

Dari seluruh hasil aktivitas siswa yang teramati oleh pengamat pada saat proses pembelajaran berlangsung didapatkan jumlah nilai 48 dan nilai rata-rata 3,4. nilai 3,4 adalah hasil rata-rata dibagi jumlah (14) yaitu Jumlah aktivitas siswa yang diamati saat proses pembelajaran.

$$
\mathrm{X}=\frac{\sum X i}{N}=\frac{48}{14} 3,4
$$

Berdasarkan tabel 3 memperlihatkan rata-rata aktivitas siswa yang diamati pada siklus I adalah 3,4. Nilai 3,4 memperlihatkan bahwa aktivitas siswa selama mengikuti pembelajaran pada materi menulis dengan menggunakan media pada materi kata dan kalimat sekolah dasar termasuk pada kategori cukup.

Berdasarkan hasil belajar siswa setelah diterapkan penggunaan media bermain botol pada materi menulis kata dan kalimat siswa sekolah dasar, menunjukan bahwa ketuntasan hasil belajar mencapai 78,26. Hasil yang diperoleh melebihi dari nilai KKM 65. Dengan demikian dapat diklasifikasikan hasil belajar berada pada kategori 
26 Pengembangan keterampilan menulis dengan menggunakan media untuk meningkatkan hasil belajar di sekolah dasar - Adnan, Riski Kurniawati

baik. Data hasil analisis data diketahui kemampuan siswa menulis kata dan kalimat menggunakan media bermain botol pada siklus II masih ada 2 siswa yang masih memiliki nilai belum tuntas belajar secara individual sebagaimana terlihat pada tabel dibawah ini:

Tabel 2. Klasifikasi nilai hasil belajar siswa siklus II

\begin{tabular}{|l|l|l|l|}
\hline Nilai & Klasifikasi & Frekwensi & Persentase' \\
\hline $86-100$ & $\begin{array}{l}\text { Sangat } \\
\text { baik }\end{array}$ & 5 & $22 \%$ \\
\hline $76-85$ & baik & 9 & $39, \%$ \\
\hline $66-75$ & Cukup & 7 & $30,4 \%$ \\
\hline $50-65$ & Kurang & 2 & $8,6 \%$ \\
\hline $0-49$ & $\begin{array}{l}\text { Sangat } \\
\text { Kurang }\end{array}$ & - & - \\
\hline & Jumlah & 23 & $100 \%$ \\
\hline
\end{tabular}

Dari tabel diatas dapat diketahui siswa yang memperoleh nilai sangat baik(86-100) 5 siswa (22\%), siswa yang memperoleh nilai baik( $76-85)$ 9 orang siswa (39\%), siswa yang memperoleh nilai cukup (66-75) sebanyak $7(30,4 \%)$ siswa, siswa yang memperoleh nilai kurang (50-65) sebanyak $2(8,6 \%)$ siswa serta siswa yang memperoleh nilai sangat kurang (0-49) tidak ada siswa.

Berdasarkan tes hasil belajar siswa siklus II menggunakan media bermain botol pada materi menulis kata dan kalimat, menunjukan jumlah siswa yang mencapai ketuntasan secara individual adalah 21 orang siswa, dan yang mencapai ketuntasan secara klasikal nilai rata-rata adalah 78,26 kalau dan nilai 78,26 berada sesuai dengan tuntutan KKM klasikal yang ditetapkan sekolah, maka penerapan media pada materi menulis kata dan kalimat siklus II sekolah dasar sudah tercapai.

Dari seluruh hasil aktivitas siswa yang teramati oleh pengamat pada saat proses pembelajaran berlangsung didapatkan jumlah nilai 60 dan nilai rata-rata 4,2. nilai 4,2 adalah hasil rata-rata dari jumlah (14) yaitu jumlah aktivitas siswa yang diamati saat proses pembelajaran

$\mathrm{X}=\frac{\sum X i}{N}=\frac{60}{14}=4,2$

Nilai 4,2 memperlihatkan bahwa aktivitas siswa selama mengikuti pembelajaran pada materi menulis dengan menggunakan media pada materi kata dan kalimat termasuk pada kategori Baik.

Dari hasil analisa data dapat penulis gambarkan bahwa terdapat peningkatan hasil belajar siswa pembelajaran menulis kata dan kalimat menggunakan media bermain botol yang ditunjukkan pada siklus I dengan nilai rata-rata 61,96 dan siklus II dengan nilai 78,26, berikut ini rekapitulasi hasil belajar siswa siklus I dan siklus II

Tabel 3. Rekapitulasi hasil belajar siklus I dan II

\begin{tabular}{|l|l|l|}
\hline Siklus & Nilai rata-rata & Kategori \\
\hline I & 61,9 & Cukup \\
\hline II & 78,26 & Baik \\
\hline
\end{tabular}

Aktivitas siswa dapat digambarkan bahwa terdapat peningkatan dalam menulis kata dan kalimat menggunakan media bermain botol ditunjukkan pada siklus I dengan skor rata-rata 3,4 termasuk kategori cukup dan pada siklus II dengan nilai 4,2 termasuk kategori baik. Untuk lebih jelas dapat dijelakan pada rekapitulasi berikut:

Tabel 4. Rekapitulasi aktivitas siswa siklus I danII

\begin{tabular}{|l|l|l|}
\hline Siklus & Nilai rata-rata & Kategori \\
\hline I & 3,4 & Cukup \\
\hline II & 4,2 & Baik \\
\hline
\end{tabular}

Pengembangan ketrampilan menulis kata dan kalimat menggunakan media pada siswa sekolah dasar menjadi lebih menarik, suasana belajar lebih menyenangkan dan efektif. Penggunaan media dapat meningkatkan minat 
27 Pengembangan keterampilan menulis dengan menggunakan media untuk meningkatkan hasil belajar di sekolah dasar - Adnan, Riski Kurniawati

belajar siswa hal ini disebabkan karena media merupakan sesuatu yang baru digunakan oleh siswa. siswa lebih terampil dan mudah dalam menulis kata dan kalimat dengan baik dan benar.

Berdasarkan hasil belajar pada siklus I didapatkan bahwa ketuntasan secara klasikal belum tuntas hal ini disebabkan sedikit siswa yang cendrung dominan mau belajar dan selanjutnya kekurangan pada siklus I diperbaiki pada siklus II agar siswa lebih aktif lagi. dari hasil belajar siswa setelah pelaksanaan tindakan II menunjukkan jumlah siswa mencapai ketuntasan sebanyak 21 orang siswa (91,3\%), sedangkan dua orang $(8,7 \%)$ yang lain belum mencapai ketuntasan, rata-rata hasil belajar siswa diperoleh 78,26 sudah diatas KKM yang ditetapkan sekolah. Hal ini sesuai dengan makalah sebelumnya, menyatakan bahwa kalimat merupakan satuan bahasa terkecil dalam mewujudkan atau tulisan yang mengungkapkan pikiran yang utuh, sehingga terdapat pengaruh yang signifikan antara kemampuan kosakata dan struktur kalimat terhadap kemampuan menulis paragraph

Ketercapaian ketuntasan belajar secara klasikal menggunakan media pada materi menulis kata dan kalimat dikategorikan berhasil dalam dua siklus, dengan demikian penggunaan media merupakan salah satu cara membantu siswa dalam meningkatkan kemampuan menulis kata dan kalimat. Terkait dengan penelitian sebelumnya untuk meningkatkan hasil berlajar siswa dalam kemampuan menulis, perlu ditunjang dengan pemakaian media pembelajaran. Kualitas pembelajaran membaca dan menulis permulaan dikelas 1 sekolah dasar melalui media kata bergambar, membuat siswa menarik dalam kegiatan pembelajaran. Sehingga metode ini dianggap efektif siswa cepat mengeja dan siswa bisa membaca dan menulis

Selanjutnya, penggunaan media kartu kata dapat meningkatkan kemampuan membaca bagi anak lambat belajar (anak kebutuhan khusus), hasil yang didperoleh sesuai dengan tingkatan kemampuan anak tersebut[5]. Pengunaan tidak hanya pada media sederhana saja, misalnya kartu atau medi acetak lainnya, adapun media yang dikembangkan dengan memanfaatkan "sms" sebagai media pengajaran membaca dan menulis pada kelas rendah, hasil yang diperoleh adalah dapat dijadikan solusi alternatif oleh guru dan siswa mampu membaca, nyaring kalimat sederhana dengan lafal dan intonasi yang tepat serta siswa dapat memahami pesan atau isi tulisan yang dibacanya. Selain itu siswa dapat menuliskan kalimat sederhana sesuai dengan kaidah bahasa Indonesia dan menyampaikan pesan atau isi tulisan perihal perkenalan nama diri.

Aktivitas siswa dalam pembelajaran menulis kata dan kalimat menggunakan media botol pada siklus I yaitu 3,4 termasuk kategori cukup, sedangkan aktivitas guru pada siklus I berada pada kategori 3,5 yaitu cukup. Untuk aktivitas siswa siklus dua menunjukan kategori baik yaitu nilanya 4,2 dan untuk aktivitas guru pada siklus II berada pada nilai 4,6 termasuk kategoti baik.

\section{SIMPULAN}

Berdasarkan penggunaan media untuk mengembangkan ketrampilan menulis kata dan kalimat pada siswa sekolah dasar, dapat dilihat dari hasil belajar siswa pada siklus I dengan ratarata nilai 61,96 (kurang) meningkat menjadi 78,26 pada siklus II sehingga berada pada kategori baik. Selain itu penggunaan media juga dapat meningkatkan aktivitas siswa dalam kegiatan pembelajaran menulis kata dan kalimat. Dilihat dari hasil peningkatan aktivitas siswa yang pada siklus I mencapai 3,4 menjadi 4,2 pada siklus II. 
28 Pengembangan keterampilan menulis dengan menggunakan media untuk meningkatkan hasil belajar di sekolah dasar - Adnan, Riski Kurniawati

\section{DAFTAR PUSTAKA}

Arikunto, Suharsimi. 2010. Prosedur Makalah, Suatu Pendekatan Praktik. Edisi Revisi. Jakarta: Rineka Cipta.

Aqib, Zainal. 2009. Makalah Tindakan Kelas. Bandung: CV Rama Widya.

Arsyad, Azhar, 2011. Media Pembelajaran. Jakarta: Raja Grafindo Persadah

Djamarah. 1995. Strategi Belajar Mengajar. Jakarta: Rineka Cipta

Misdar. 2013. Meningkatkan Kemampuan Membaca Permulaan Melalui Media Kartu Kata Bagi Anak Lambat Belajar. Jurnal Ilmiah Pendidikan Khusus. Volume 1 Nomor 1. Hlm. 502-514.

Munirah dan Hardian. 2016. Pengaruh Kosakata Dan Struktur Kalimat Terhadap Kemampuan Menulis Paragraph Deskripsi Siswa SMA. Jurnal Pendidikan Bahasa dan sastra. Volume 16 Nomor 1. Hlm: 78-87

Muliyanti. 2005. Modul Membaca dan Menulis Permulaan. Bandung: FBS UPI

Nuraini. 2011. Pembelajaran Bahasa Indonesia. Banda Aceh: Universitas Syiah Kuala.

Purnamawati dan Eldarni. 2011. Media Sebagai Alat Pembelajaran. Jakarta: Rineka Cipta

Sudijono, Anas. 2011. Pengantar Statistik Pendidikan. Jakarta: PT Raja Grafindo

Sukartiningsih, Wahyu. 2004. Peningkatan Kualitas Pembelajaran Membaca Dan Menulis Permulaan Di Kelas 1 Sekolah Dasar Melalui Media Kata Bergambar. Jurnal Pendidikan Dasar. Volume 5 Nomor 1. Hlm. 51-60.

Sumardi. 2011. Pemanfaatan "SMS" Sebagai Media Pengajaran Membaca dan Menulis Permulaan Dikelas Rendah. Jurnal Makalah Pendidikan Volume 12 nomor 1. Hlm 22-28. 